\title{
PRACA W GRUPACH JAKO FORMA REALIZACJI CELÓW KOMUNIKACYJNYCH I REFLEKSJI NAD JĘZYKIEM
}

\author{
Teamwork as a form of achieving communicative goals \\ and reflection on language
}

Language learning in cooperation is a social and sociocultural dimension of action-based approach. By means of language education the school prepares students to undertake social activities and to cooperate with native language speakers. Therefore, teamwork teaching and learning, team pursuance of mutual goals with the use of foreign language has become one of the priorities of action-based didactics.

We usually talk about positive aspects of teamwork in the context of communication teaching. Team cooperation is less frequently perceived as a form of pursuing another goal of language education, i.e. linguistic competence development. Apart from pursuing communicative goals work in small groups lets the learners get involved in explicit work with language structures, observe and discover language rules, test formed hypotheses in texts they create and master their competencies by reflecting on the language.

The purpose of the paper is to present organisational forms of classes applied most frequently in foreign language teaching and learning actionbased process.

\section{Wprowadzenie}

Idea współpracy między uczniami nie zrodziła się wraz z podejściem zadaniowym, lecz pojawiła się już w latach 60. (C. Freinet i P. Freire), a wzbudziła nowe zainteresowanie $w$ latach 80. (podejście komunikacyjne i Task Based 
Learning). W podejściu zadaniowym zaproponowanym przez Europejski system opisu kształcenia językowego ${ }^{1}$ praca w grupach na lekcji języka stała się podstawową formą organizacyjną zajęć.

Wykonując zadania, uczniowie angażują się w działania, które mają przede wszystkim na celu odkrywanie i przekazywanie znaczeń. Ale rozwijanie kompetencji komunikacyjnych nie wyczerpuje w pełni potencjału tkwiącego w zespołowym działaniu uczących się. Praca w grupach umożliwia również obserwację i analizę form językowych w kontekstach, identyfikację zagadnień gramatycznych, wysuwanie hipotez i ich weryfikację. Poprzez zaangażowanie uczących się w eksplicytną pracę na strukturach językowych, rozwijanie ich kompetencji staje się bardziej efektywne.

\section{Istota uczenia się we współpracy}

Uczenie się we współpracy to wymiar społeczny i socjokulturowy podejścia zadaniowego lansowanego przez System opisu. Definiując zadanie, autorzy dokumentu stwierdzają: „Zarówno uczących się, jak i użytkowników języka postrzega się przede wszystkim jako aktywne 'jednostki społeczne', czyli członków określonego społeczeństwa, mających do wykonania pewne zadania (...). Posługujemy się przy tym pojęciem zadania, jako że chodzi tu o działania realizowane przez jedną lub więcej osób, które angażując w sposób strategiczny swoje kompetencje zmierzają do ściśle określonego celu komunikacyjnego" (ESOKJ, 2003: 20). Poprzez kształcenie językowe szkoła przygotowuje uczniów do wykonywania zadań społecznych, do współpracy z rodzimymi użytkownikami języka. Wynika stąd jasno, że jednym z priorytetów dydaktyki zadaniowej jest nauczanie i uczenie się kolektywnego działania, zbiorowej realizacji wspólnego celu przy użyciu języka obcego.

Współpraca zakotwicza uczenie się w kontekście społecznym, uczy solidarności, współodpowiedzialności, umożliwia autentyczne działania komunikacyjne. Cel socjokulturowy nabiera w tej sytuacji wyrazistego kształtu: działanie wraz z innymi to uznanie i respektowanie ich wartości, wzajemne zrozumienie i tolerancja. Uczenie się jest postrzegane jako uczestnictwo $\mathrm{w}$ społecznym procesie konstruowania wiedzy, jako "transformacja społeczna jednostek i ich otoczenia” (Springer, 2009: 31). Przestrzegając wspólnych reguł, respektując wzajemnie odgrywane role, zespół uczących się pracuje nad osiągnięciem zakładanego celu.

\footnotetext{
${ }^{1}$ Rada Europy. 2003. Europejski system opisu kształcenia językowego: uczenie się, nauczanie, ocenianie, Warszawa: Wydawnictwa CODN; skróty używane w artykule to: Europejski system opisu kształcenia językowego, Europejski system, System opisu, ESOKJ.
} 
Dobrodziejstwa uczenia się we współpracy można scharakteryzować w następujący sposób: jednostki społeczne mają do wykonania lub wyznaczają sobie kompleksowe zadania o wyraźnie określonym celu; wspólnie podejmują decyzje dotyczące sposobu postępowania; niekoniecznie wszyscy robią to samo w tym samym czasie; mają dostęp do rozmaitych środków i materiałów; przetwarzają dużą ilość autentycznych informacji; wchodzą $w$ interakcje nie tylko ze sobą, ale również z osobami z zewnątrz (takimi, jak np. eksperci, inne osoby z otoczenia); angażują się w proces odkrywania/konstruowania wiedzy; analizują, oceniają swoje działania i stosowane środki; przekazują sobie wzajemnie wiedzę, dzielą się nią; dokonują samooceny na przestrzeni całego procesu, aby osiągnąć jak najlepszy wynik; rozwijają nowe kompetencje uczestnicząc w działaniu; nowo nabyte kompetencje mają równocześnie charakter indywidualny, społeczny, transwersalny i specyficzny (por. Brossard, 1999).

Odnosząc tę ogólną filozofię kształcenia językowego do konkretnego działania nauczycieli i uczniów w perspektywie zadaniowej, rozważymy tutaj kwestię realizacji zadań w systemie klasowo-lekcyjnym na zasadzie współpracy i współdziałania.

\section{Podstawowe formy organizacyjne zajęć}

W tekstach Europejskiego systemu nie znajdujemy bezpośrednich zaleceń odnośnie metod nauczania czy form organizacyjnych zajęć, wynikają one z filozofii samego dokumentu. Również wszelkie inne publikacje glottodydaktyczne nie narzucają tutaj żadnych modeli, nie udzielają definitywnej odpowiedzi, kiedy stosować pracę indywidualną, pracę w parach, w małych zespołach (3-4 osoby) lub większych grupach (np. podział klasy na 2 grupy), pracę „równym frontem”. Ich wybór jest uzależniony od takich składników procesu jak: typ zadania, cechy uczących się, realizowane cele, podejmowane działania językowe, rodzaj stosowanych materiałów etc. Dynamiczny przebieg procesu uczenia się wymaga kombinacji różnych form organizacyjnych. Najczęściej decyzję podejmuje nauczyciel i/lub autor podręcznika. Każda z wymienionych tutaj form organizacyjnych zajęć będzie skuteczna, jeżeli nauczyciel dostosuje ją do warunków, w których przebiega kształcenie językowe.

\subsection{Praca w kilkuosobowych zespołach}

Czym charakteryzuje się praca w kilkuosobowych zespołach na zajęciach z języka i jakie korzyści wynikają z tej współpracy dla uczestników procesu dydaktycznego? Międzynarodowe badania nad stosowaniem podejścia za- 
daniowego w praktyce szkolnej dostarczyły wiele ciekawych spostrzeżeń na temat współpracy uczących się w trakcie wykonywania zadań (zob. Baggio et al., 2004). Przedstawiamy poniżej pięć głównych zasad sformułowanych przez uczestników projektu Tabasco².

Pierwsza z nich to zasada „pozytywnej współzależności”. Uczący się potrzebują się wzajemnie, aby pomyślnie wykonać zadanie; jeżeli dane zadanie można dobrze lub nawet lepiej wykonać indywidualnie, nie powinno się organizować uczenia się w grupie, we współpracy. Zadanie musi w pewien sposób dotyczyć wszystkich członków zespołu, musi występować zjawisko „pozytywnej współzależności". Grupa posiada wspólny cel, a każdy z jej uczestników pracuje nad innym aspektem zadania, pełni przydzieloną mu funkcję, korzystając ze wspólnych środków, którymi grupa dysponuje. Fakt, że każdy członek grupy odgrywa inną rolę, że przydziela mu się inne zadanie cząstkowe, zależy od rodzaju zadania, wspólnych celów i produktu końcowego.

Kolejną zasadą jest wzajemna pomoc i uczenie się od innych. Doświadczenie życiowe oraz poziom wiedzy i umiejętności uczestników grupy nie są nigdy identyczne, dlatego z korzyścią dla wszystkich jest wzajemna pomoc w pokonywaniu trudności. Uczestnicy grup cieszą się swoistego rodzaju swobodą. Pracując w małych zespołach, wypróbowują propozycje swoich kolegów. Każdy może być źródłem wiedzy dla innych, dla zespołu. Pomagają sobie wzajemnie, zachęcają jeden drugiego do pracy, do wysiłku, dyskutują, wyjaśniają trudne problemy, dzielą się posiadaną wiedzą, szukają powiązań pomiędzy wiedzą nabytą uprzednio i nową. Jedni uczą się od drugich, wyjaśniając sobie to, co sprawia im trudności. Ci, którzy uczą się szybciej dostarczają wyjaśnień tym, którzy uczą się wolniej. Ci ostatni czują się bezpieczniej pod opieką kolegów.

Trzecia z kolei reguła to współodpowiedzialność. Współpraca jest tutaj synonimem współodpowiedzialności. Każdy uczestnik jest odpowiedzialny za swój indywidualny wkład pracy oraz za wyniki całego zespołu. Współpraca przynosi korzyści każdemu uczestnikowi zespołu (indywidualna odpowiedzialność uczestników grupy). Działania uczestników podlegają nieformalnej ewaluacji zespołu, a ci, którzy nie są w stanie samodzielnie wykonać powierzonego

2 Projekt Lingua TABASCO (Task based school organisation for the acquisition of language in Europe) został zrealizowany w latach 2000-2003 w wyniku współpracy sześciu instytucji z sześciu krajów europejskich; badania dotyczyły wielu aspektów procesu nauczania i uczenia się w podejściu opartym na wykonywaniu zadań; część wyników badań opublikowano w Travaux de didactique du français langue étrangère $n^{\circ} 51 / 2004$, I.E.F.E. Université Paul-Valéry, Montpellier. 
im zadania cząstkowego, czynią to w asyście któregoś z członków grupy. Ekipy są odpowiedzialne za realizację zadań, za współpracę.

Respektowanie norm i zasad społecznych to następna wymieniana zasada. Sala lekcyjna staje się terenem rozmaitych działań społecznych, dlatego przestrzeganie niezbędnych reguł i zasad społecznych ułatwia uczącym się komunikację i współpracę. Zachowanie tych norm ma wpływ na interakcje w grupie; wszyscy uczniowie wykonujący zadanie mają możność oceniania i komentowania, argumentowania przeciw - lub na korzyść - raczej idei niż osób. Aby grupa mogła prawidłowo i skutecznie funkcjonować, jej uczestnicy muszą umieć prosić o informacje, udzielać informacji, wyjaśniać, streszczać, dodawać odwagi, likwidować napięcia. Niezbędne jest również nauczanie eksplicytne umiejętności przewodzenia (komunikacja, zaufanie, zdolność rozwiązywania konfliktów).

I wreszcie ostatnia zasada dotyczy refleksji zespołowej nad przebiegiem uczenia się. Czynić postępy znaczy dostrzegać nie tylko efekty pozytywne uczenia się ale również niedociągnięcia i braki. Krótkie chociażby podsumowanie danej jednostki (fazy) przynosi liczne korzyści. Uczący się i nauczyciel dyskutują nad następującymi problemami: jakie cele zostały osiągnięte? Czy relacje w czasie pracy pomiędzy członkami zespołu były skuteczne? Co oznaczają rezultaty dla przyszłej współpracy? Które działania indywidualne były bardziej lub mniej produktywne? A więc ekipy stworzone dla uczenia się we współpracy dostarczają realnego kontekstu do rozwijania wzajemnego zrozumienia. Ważnym czynnikiem jest stworzenie sprzyjającej atmosfery, zachęcającej do wypowiedzi i kreatywności.

Taki sposób uczenia się to ciągłe odnawianie doświadczeń, refleksji, konceptualizacji, aktywnego eksperymentowania. Realizacja zadań w kilkuosobowych zespołach umożliwia użycie języka jako narzędzia uczenia się i komunikacji oraz refleksję uczącego się nad językiem, dostarcza również informacji zwrotnej na temat osiąganych wyników.

\subsection{Praca indywidualna}

Trudno sobie wyobrazić wykonywanie zadań bez pracy indywidualnej uczniów. Słuchanie, czytanie, oglądanie programów telewizyjnych i nagrań wideo, wykonywanie prac pisemnych na lekcji i zadań domowych - oto przykłady działań realizowanych indywidualnie przez uczących się. Nie pozostają one w sprzeczności z pracą grupową, która je poprzedza lub po nich następuje. Jakie korzyści przynosi praca indywidualna? Pracując bez pomocy nauczyciela czy kolegów, uczący się rozwija swoją autonomię, przyzwyczaja się do samodzielnego podejmowania decyzji. Niekorzystnym zjawiskiem jest 
tylko brak bezpośredniej kontroli działań językowych i zwiększone ryzyko popełniania błędów w porównaniu z pracą w grupach. Chociaż wykonywanie zadań wymaga w wielu sytuacjach współdziałania i współpracy uczących się, zadania wykonywane indywidualnie pozwalają uczniowi pracować we właściwym mu rytmie, stosować odpowiadające mu strategie i rozwijać swoje zainteresowania. Teoretycy twierdzą (zob. Skehan, 1998, Ellis, 2003), iż, podobnie jak interakcje społeczne, realizacja zadań oparta na indywidualnej pracy ucznia przyczynia się do rozwoju jego interjęzyka.

\subsection{Praca „równym frontem”}

W trakcie realizacji zadań występuje wiele takich sytuacji, gdzie praca z całym zespołem jest bardzo wskazana. Dotyczy to głównie dwóch faz wykonywania zadań: fazy przedzadaniowej i pozadaniowej. Praca z całym zespołem ma często na celu pełniejsze wykorzystanie wyników uczenia się przebiegającego w małych grupach. Problemy nad którymi pracują małe ekipy stają się następnie centrum zainteresowań całej klasy. Można to nazwać dzieleniem się wynikami z innymi. Efekty pracy poszczególnych zespołów, odkryte reguły, wyrażane opinie, argumenty etc. uzupełniają się w trakcie prezentacji, składają się na ogólny, całościowy obraz danego zagadnienia. Wywołują zainteresowanie i reakcję nauczyciela, stymulują go do zajęcia stanowiska. Przygotowanie uczniów do wykonywania zadań w zespołach oraz prezentacja wyników pracy po ich realizacji - to dla nauczyciela stosowny moment do udzielania rad, koncentrowania uwagi na istotnych elementach lekcji, ukierunkowania działań, dostarczenia i uzupełnienia brakujących treści językowych, podsumowań, wyjaśniania trudności.

Pracę „równym frontem” stosuje się najczęściej na początku i na końcu zajęć (por. Willis, 1996). Na etapie przedzadaniowym - w celu prezentacji tematyki i zadania. Nauczyciel informuje wszystkich uczących się, na czym polega zadanie, jakiej wiedzy i umiejętności wymaga jego wykonanie, jakie materiały będą potrzebne, udziela również wskazówek odnośnie podziału zespołu na grupy, przydziału ról. Praca z całym zespołem to również forma zajęć preferowana w działaniach przygotowujących studentów do odbioru tekstów słuchanych i czytanych, mających na celu antycypację ich treści i wysuwanie hipotez. Na etapie końcowym - w celu podsumowania i ewaluacji zadań oraz wyjaśnienia (ewentualnie przećwiczenia) struktur leksykalnych i gramatycznych, które nastręczały studentom trudności w trakcie wykonania zadań.

Z obserwacji wynika, iż, praca w małych grupach musi być wspierana innymi formami zajęć, by nie doszło do izolacji poszczególnych ekip i aby uczący się mogli dostrzec, jak przedstawiają się efekty ich działań na forum całego zespołu. 


\section{Fazy realizacji zadań a praca $w$ grupach}

Szukając prostego, uniwersalnego modelu realizacji zadań, który z łatwością można by zastosować na zajęciach z języka obcego w codziennej praktyce pedagogicznej, odwołujemy się do koncepcji takich autorów, jak Willis (1996), Ellis (2003), Estaire (2009), którzy proces realizacji zadania dzielą na trzy zasadnicze etapy: działania przed, w trakcie i po zakończeniu zadania, czyli: przygotowanie zadania, jego realizacja oraz etap po realizacji zadania.

Jeśli chodzi o zależność między formami organizacyjnymi zajęć a fazami realizacji zadań, stwierdzić należy, iż nie ma tutaj żadnych kanonów, można jedynie mówić o preferencjach podyktowanych warunkami kształcenia. Nauczanie/ uczenie się przez wykonywanie zadań wymaga stosowania wszystkich powszechnie przyjętych struktur organizacyjnych zajęć, takich jak praca indywidualna, praca w kilkuosobowych zespołach oraz praca „równym frontem”. Wybór formy jest uzależniony m.in. od specyfiki fazy, w której jest stosowana.

Obserwacja procesu lekcyjnego wskazuje na pewne implicytne zasady, którymi kierują się najczęściej dydaktycy (por. Willis, 1996, Estaire, 2009). Przed przystąpieniem do realizacji zadania, wszelkie czynności organizacyjne nie wymagają na ogół żadnych podziałów uczących się, wręcz przeciwnie, uwagi nauczyciela kierowane są do całego zespołu. I jeśli nawet już na tym etapie następuje przydział ról i zadań cząstkowych, wszyscy uczniowie muszą orientować się, czym będą zajmować się ich koledzy, by uświadomić sobie typ powiązań i współzależności poszczególnych zespołów.

Natomiast zróżnicowanego podejścia wymaga niekiedy wprowadzenie do tematyki zajęć. Na przykład, antycypacja treści tekstu, który ma być słuchany czy czytany, odbywa się bądź to w oparciu o pracę w kilkuosobowych zespołach (interpretacja zagadnienia w małych grupach i przedstawienie wyników, wniosków wszystkim kolegom), bądź na forum całej grupy uczących się (np. wstępna debata na dany temat - niekiedy w oparciu o jakiś dodatkowy dokument). $\mathrm{W}$ tej fazie wstępnej uczniowie wypowiadają się na podstawie własnego doświadczenia językowego, uruchamiając posiadaną wiedzę i umiejętności.

Realizacja przydzielonych zadań (najczęściej w oparciu o tekst czy dokument ikonograficzny) wymaga pracy w parach lub małych grupach. Odkrywanie znaczeń, obserwacja struktur językowych, formułowanie wypowiedzi, szukanie rozwiązań etc. - wszystkie te działania stają się bardziej kompleksowe, autentyczne, bogatsze, jeżeli angażuje się w nie kilka osób. Dzięki takiej współpracy zróżnicowany poziom wiedzy uczestników grupy pozwala osobom słabszym uczyć się od innych i czynić postępy.

W fazie pozadaniowej, takie działania, jak: podsumowanie zadania, wnioski, analiza trudności i błędów, dodatkowe wyjaśnienia gramatyczne, 
ewaluacja pracy zespołów etc. dotyczą wszystkich uczących się, a więc odbywają się najczęściej na forum całego zespołu.

\section{Mocne i słabe strony pracy zespołowej}

Jak twierdzi Gołębniak (2004: 183), „tworzenie wspólnoty osób uczących się oparte jest na zjawisku synergii. Ta kolektywna energia uaktywnia się wtedy, gdy ludzie pracują razem. W pojedynkę nie jest się w stanie wykonać rzeczy, które stają się rezultatem pracy wspólnej". Praktyka pedagogiczna potwierdza opinię, iż praca w kilkuosobowych podzespołach posiada wiele atutów i umożliwia efektywne wykonywanie zadań (uczenie się z innymi i od innych, bezstresowe wykonywanie zadań, rozwijanie autonomii, mnogość interakcji, różne rodzaje dyskursu etc.). Nie oznacza to jednak, iż ta forma organizacyjna zajęć jest zawsze skuteczna i przynosi spodziewane efekty. W licznych publikacjach glottodydaktycznych (zob. np. Kruszewski, 2005) specjaliści podają przykłady nieprawidłowego funkcjonowania grup oraz zakłóceń procesu nauczania/uczenia się w trakcie wykonywania zadań.

\subsection{Pozytywne aspekty pracy $w$ grupach}

Porównując efekty pracy w parach lub małych grupach z efektami pracy „równym frontem” Ellis (2003: 267) wymienia całą listę korzyści przemawiających za stosowaniem tej formy organizacyjnej zajęć. Są to:

- mnogość interakcji: pracując w parach lub małych grupach, uczniowie mają więcej czasu na operowanie językiem. W nauczaniu frontalnym czas ten w $80 \%$ wykorzystuje nauczyciel;

- zróżnicowanie dyskursu: w nauczaniu skoncentrowanym na nauczycielu gros wypowiedzi uczących się to odpowiedzi na pytania, natomiast podczas pracy w grupie reakcje językowe uczniów są bardziej zróżnicowane, dotyczą przekazywania i negocjowania znaczeń w sytuacjach autentycznych;

- wyższy stopień indywidualizacji: w nauczaniu frontalnym uczniowie pracują według instrukcji i pod nadzorem nauczyciela; podczas uczenia się w grupach reakcje i wypowiedzi uczących się mogą być bardziej zindywidualizowane;

- zmniejszenie stresu i zdenerwowania: wypowiedzi na forum całej klasy wywołują większy stres i zdenerwowanie niż praca w parach lub małych zespołach. 
Praca w grupach jako forma realizacji celów komunikacyjnych i refleksji...

- Wzmocnienie motywacji: w grupach nie występuje tak wysoki stopień rywalizacji, jak to ma miejsce na forum całego zespołu; uczniowie chętniej pomagają sobie.

- Interakcje między uczącymi się: interakcje między uczącymi się są zredukowane do minimum $w$ nauczaniu skoncentrowanym na nauczycielu - podstawowy schemat to nauczyciel - uczeń; w uczeniu się w grupach przeważają interakcje uczeń - uczeń.

- Większy stopień niezależności uczących się podczas pracy w grupach.

- Integracja społeczna: uczniowie mają okazję lepiej się poznać i zrozumieć.

- Współpraca z rówieśnikami: praca równym frontem nie sprzyja współpracy z innymi, praca w grupach umożliwia rozwijanie współpracy z różnymi osobami.

- Zwiększenie efektywności uczenia się: uczestniczenie w rozwiązywaniu problemów w grupie przyczynia się do przejęcia odpowiedzialności za swoje uczenie się.

Podsumowując stwierdzić należy, iż praca w grupach na zajęciach z języka obcego posiada wiele zalet. Stwarza ona możliwość wykorzystania wszystkich kanałów komunikacji: aktywnego słuchania, mówienia do siebie i do innych, czytania, pisania oraz budowania sprzyjającej atmosfery do rozwijania innych kompetencji, niekoniecznie językowych, np. uczenia się we współpracy, negocjowania, dyskutowania, kierowania pracą innych (Gołębniak, 2004: 183).

\subsection{Słabe strony uczenia się $w$ grupach}

W trakcie prowadzonych przez nas badań empirycznych (zob. Janowska, 2011), wśród negatywnych zjawisk odnotowano m.in.: unikanie wysiłku i obchodzenie przydzielanych ról, korzystanie z pracy innych, niechętne zabieranie głosu, porozumiewanie się w języku ojczystym (lub np. angielskim znanym na ogół wszystkim uczestnikom wielonarodowościowych kursów), praca w bardzo wolnym tempie etc. Uwagi te dotyczą głównie zespołów 4-5 osobowych, natomiast w korzystniejszym świetle przedstawia się praca w trójkach i w parach. W trakcie badań zaobserwowano, że jest to najbardziej skuteczna forma podziału studentów. Łatwiej jest zaktywizować dwie lub trzy osoby niż liczniejsze zespoły.

Istnieją więc sytuacje, gdy praca w grupach nie przynosi oczekiwanych efektów, co wskazuje na niedoskonałości tej formy organizacyjnej zajęć (zob. Kruszewski, 2005: 185, Estaire, 2009: 98-99). Przytaczamy poniżej kilka przykładów trudności na jakie napotykają uczestnicy procesu dydaktycznego opartego na uczeniu się w kilkuosobowych podzespołach. 
- Niektórzy uczniowie czy studenci nie są przyzwyczajeni do pracy zespołowej, nie pociąga ich ta forma uczenia się, nie akceptują jej. Formalne uczestnictwo w pracy grupy nie oznacza wcale ich zaangażowania się $\mathrm{w}$ wykonywanie zadań. Jeśli pracują, to z konieczności i mało efektywnie.

- Praca w zespole wymaga ciągłej koncentracji uwagi na treściach i formie wypowiedzi, co stanowi duże obciążenie umysłowe uczestników zajęć. Ponadto uczniowie mogą mieć trudności w śledzeniu i ocenie poprawności wypowiedzi swoich kolegów, zwłaszcza gdy chodzi o korygowanie błędów. Praca w grupach przebiega często kosztem najlepszych członków zespołu.

- Mierne efekty pracy grupowej są często wynikiem nieprawidłowej postawy nauczyciela. Pełna autonomia uczących się jest w praktyce prawie nieosiągalna (Wilczyńska, 1999). Brak efektywnej pomocy, złożenie na barki uczniów całego ciężaru ucznia się i odpowiedzialności za osiągane wyniki przekracza ich możliwości.

- Warunki uczenia się w sali lekcyjnej (np. jej umeblowanie) oraz duża liczba uczniów nie sprzyjają efektywnemu przyswajaniu języka w grupach. Nadmierny hałas przeszkadza w interakcjach i koncentracji na danym zagadnieniu, nie wspominając już o poprawności językowej.

- Zdarza się, iż praca zespołu nie przebiega zgodnie z ustalonym planem i wskazówkami nauczyciela; grupa nie podejmuje zasadniczych wątków zadania, pracuje chaotycznie, pobieżnie lub też zajmuje się czymś innym (uczący się prowadzą luźne rozmowy, czytają lub przeglądają prasę, zdjęcia).

- Nieporozumienia, spory utrudniają pracę, bądź ją uniemożliwiają. Nie wszyscy w zespole akceptują przydzielone im funkcje, niektórzy niechętnie podejmują się wyznaczonej roli lub też nie chcą współpracować z zespołem, którego skład lub lider im nie odpowiada.

- W przypadku zajęć z języka obcego, istnieje wciąż niebezpieczeństwo porozumiewania się członków grupy w języku ojczystym lub innym wspólnym języku obcym, np. angielskim, tam, gdzie uczestnicy grup są różnych narodowości (dotyczy to np. nauczania języka polskiego jako obcego).

- Inny rodzaj złych zachowań językowych to koncentrowanie się grupy na działaniach niższego rzędu i unikanie rozwiązywania problemów wymagających większego wysiłku umysłowego i koncentracji (np. tworzenie wypowiedzi ustnej czy pisemnej w oparciu o znane już schematy w miejsce posługiwania się trudniejszymi strukturami).

Przedstawiliśmy tutaj tylko nieliczne przykłady niepożądanych zachowań i działań uczestników zespołów. Z powyższych refleksji wynika wniosek, iż, w trosce o pozytywne efekty uczenia się $w$ grupach, organizowanie pracy zespo- 
Praca w grupach jako forma realizacji celów komunikacyjnych i refleksji...

łowej powinno być poprzedzone dyskusją, omówieniem reguł gry, wyjaśnieniem zasad współpracy. W ten sposób uczniowie powoli oswoją się z tą techniką pracy.

\section{Uczenie się komunikacji a refleksja nad językiem}

Szkolne nauczanie języka obcego, niezależnie od stawianych celów komunikacyjnych, powinno zawsze uwzględniać nauczanie podsystemów językowych, gdyż jedynie taka dwutorowość może przynieść spodziewane efekty. Należy jedynie tak pokierować procesem, by nauczania struktur gramatycznych nie stało się priorytetem.

Rozważymy poniżej, w jakim stopniu praca w grupach umożliwia realizację tych dwóch podstawowych celów kształcenia językowego: praktykowanie komunikacji (aspekt społeczny), jej uczenie się i/lub doskonalenie oraz wdrażanie do refleksji nad językiem i procesem uczenia się (aspekt kognitywny).

\subsection{Interakcje $w$ grupach}

Porównując działania dyskursywne uczniów na zajęciach prowadzonych „równym frontem" przez nauczyciela z działaniami interakcyjnymi w grupach, należy zauważyć, że w małych grupach produkcja zwiększa się ze względu na możliwości wielokrotnego zabierania głosu przez każdego ucznia. Ponadto status rozmówców oparty na zasadzie równości, usytuowanie rozmówców face à face, propozycje rozwiązań będące wynikiem współpracy zespołu - te i inne czynniki ułatwiają i pomnażają interakcje w grupie. Natomiast interakcje kierowane przez nauczyciela są uboższe i często postrzegane przez uczącego się jako ukierunkowane na ewaluację i sankcje. Interakcje wśród rówieśników są bardziej spontaniczne, oryginalne i kreatywne, a uczniowie mimo obecności nauczyciela mogą realizować swoje pomysły (niekiedy kosztem poprawności wypowiedzi). W ten sposób uczący się mogą uczestniczyć z dużą swobodą w profilowaniu tematyki i w organizacji interakcji.

Praca w grupie obejmuje dwie płaszczyzny: negocjowanie warunków wykonania zadania (interpretacja polecenia i/lub zadania, dobór struktur, szukanie i selekcja informacji, przydział ról etc.) oraz właściwa praca nad zadaniem (np. odgrywanie ról). Tę pierwszą płaszczyznę cechuje duża ilość pytań, wypowiedzi grzecznościowych, poszukiwanie konsensusu. Dlatego obserwuje się występowanie różnych rodzajów dyskursu (wypowiedzi informacyjne, potoczne rozmowy, debata). W istocie stwierdzić należy, iż pracę w grupie cechuje bogactwo i różnorodność wykonywanych zadań oraz form komunikacji i interakcji. Działania produkcji i interakcji stają się intensywniejsze na 
skutek zaangażowania się uczniów w proces kooperacji, który pozwala im dzielić się wiedzą. Jednakże wskazany jest pewien umiar, nie należy pracy w grupach traktować jako panaceum chociażby ze względu na aspekty indywidualne i relacyjne cechujące zabieranie głosu.

\subsection{Odkrywanie zjawisk językowych}

Już z samej definicji zadania pedagogicznego wynika, iż zasadniczym celem realizacji zadań w grupach jest uczenie się komunikacji. Podkreślają to specjaliści wypowiadający się na temat podejścia zadaniowego (por. Willis, 1996, Ellis, 2003, Nunan, 2004). Przytoczyliśmy w powyższych rozważaniach kilka najistotniejszych argumentów leżących u podstaw tej koncepcji. Dzisiaj przyjmuje się jednak powszechnie, iż nauczanie samej komunikacji bez odwoływania się do reguł gramatycznych nie gwarantuje efektywnego opanowania języka w warunkach szkolnych. Systematyczne poznawanie struktur językowych dopełnia i wzbogaca proces ukierunkowany na osiąganie kompetencji komunikacyjnej, przyśpiesza przyswajanie języka. Na tym polu uzyskano już konsensus, natomiast dyskusje wciąż toczą się wokół metod rozwijania kompetencji gramatycznej. ESOKJ stawia na równi kształtowanie wszystkich trzech składowych kompetencji komunikacyjnej: lingwistycznej, socjolingwistycznej i pragmatycznej, nie proponując jednak gotowych recept i sposobów osiągania celów.

Odchodząc na moment od problemu komunikacji, skoncentrujemy nasze refleksje na przyswajaniu podsystemów językowych. Potencjał jaki prezentuje współpraca uczących się w grupie, pozwala również uwzględnić ten drugi aspekt procesu. Wykonywaniu zadań komunikacyjnych w grupach może towarzyszyć efektywne poznawanie struktur językowych w kontekstach, odkrywanie i eksplicytne formułowanie reguł przez uczących się. Badanie dyskursu generowanego w grupach (Griggs, 2009) dostarczyło istotnych danych na temat przyswajania języka i uświadamiania sobie przez uczniów reguł językowych. Praca w parach lub w małych zespołach postrzegana jest jako kontekst ułatwiający uczącym się wzajemne wykorzystanie posiadanej przez nich wiedzy na temat użycia języka oraz możliwości oceny własnych wypowiedzi i wypowiedzi innych.

Odkrywanie form językowych i eksplicytne formułowanie reguł wymaga kierowania działaniami uczących się, skierowania ich refleksji na właściwe tory. Chodzi tutaj o kombinację koncepcji czysto indukcyjnej uczenia się z koncepcją, która przywiązuje wagę do działań refleksji eksplicytnej nad językiem. Inaczej mówiąc, przyswajanie struktur językowych odbywa się na dwa sposoby: indukcja reguł abstrakcyjnych, prowadząca do restrukturyzacji interjęzyka oraz świadome uczenie się form. Świadome poznawanie reguł 
gramatycznych staje się jednym z filarów podejść opartych na wykonywaniu zadań w parach lub grupach: uczniowie powinni wypowiadać się w sposób eksplicytny na temat form, funkcji i znaczeń.

Reasumując, pracując w grupach nad realizacją celów komunikacyjnych, uczniowie mogą (wręcz powinni), bez uszczerbku dla tych celów, obserwować i odkrywać reguły językowe, testować wysuwane hipotezy w swych wypowiedziach, rozważać, odkrywać prawidłowości językowe w celu doskonalenia swoich kompetencji. Podręczniki zadaniowe są tak zbudowane, aby uczący się najpierw oswoili się z nowymi strukturami w kontekstach (tekstach), próbowali odgadnąć zasady ich stosowania, a następnie - na podstawie posiadanej wiedzy oraz znaczących przykładów użycia danych struktur - starali się odkrywać i formułować reguły.

Niektóre kierunki w dydaktyce promują dzisiaj uświadamianie uczącym się zjawisk językowych za pomocą działań, które wdrażają do refleksji metalingwistycznych i które umożliwiają budowanie wiedzy na temat systemu językowego, komunikacji i uczenia się. Jak wynika z powyższych rozważań, praca w grupach stwarza także warunki umożliwiające ukształtowanie się świadomości językowej, wyobrażeń na temat języka oraz na temat uczenia się w grupach czy parach. Spontaniczne użycie na ogół nie odsłania zasadniczego problemu, dlatego świadome postrzeganie (Schmidt, 1990) jest niezbędne do przyswajania struktur językowych.

\section{Uwagi końcowe}

Odwołując się do zasad podejścia zadaniowego przedstawiliśmy istotę współpracy i współdziałania uczniów w procesie szkolnego uczenia się języka, wskazując równocześnie na źródła tej tendencji. Przegląd podstawowych form organizacyjnych zajęć odsłonił pozytywne i negatywne aspekty uczenia się w parach i kilkuosobowych zespołach. Niepożądane zjawiska dają się jednak redukować poprzez właściwe planowanie i organizację procesu lekcyjnego oraz eksplicytne nauczanie współpracy. Jeśli chodzi o realizowane cele, rozważyliśmy hipotezę o korzystnym oddziaływaniu refleksji metajęzykowej na przyswajanie języka. Chodzi o uświadomienie uczącym się faktu, iż koncentracja na przekazywaniu znaczeń nie pozostaje w sprzeczności z odkrywaniem struktur językowych, prowadzącym do eksplicytnego formułowania reguł.

Interakcje odgrywają zasadniczą rolę w akwizycji języka, a dyskretna pomoc nauczyciela umożliwia działania kontroli i refleksji nie tylko nad komunikacją w grupach, ale także nad przyswajaniem podsystemów językowych. 
Podsumowując należy jednak podkreślić, iż poszczególnych form pracy (uczenie się indywidualne, w małych zespołach, „równym frontem”) nie należy traktować jako kanonu, gdyż są one ściśle związane ze sytuacją kształcenia zaaranżowaną w klasie.

\section{BIBLIOGRAFIA}

Baggio, R. et al. 2004. „Pourquoi l'apprentissage coopératif pour l'approche Tabasco”. Travaux de didactique du français langue étrangère 51: 51-59.

Brossard, L. 1999. „Entrer dans la construction des compétences”. La vie pédagogique 112: 21. Ellis, R. 2003. Task-based Language Learning and Teaching. Oxford: Oxford University Press.

Estaire, S. 2009. El aprendizaje de lenguas mediante tareas: de la programación al aula. Madrid: Edinumen.

Gołębniak, B. D. 2004. „Nauczanie i uczenie się w klasie” (w) Pedagogika 2 (red. Z. Kwieciński, B. Śliwerski). Warszawa: Wydawnictwo Naukowe PWN: 158-205.

Griggs, P. 2009. „A propos de l'articulation entre l'agir de l'usage et l'agir de l'apprentissage dans une approche actionnelle: une perspective sociocognitive" (w) L'approche actionnelle dans l'enseignement des langues. Onze articles pour mieux comprendre et faire le point (red. M.-L. Lion-Olivieri, Ph. Liria). BarceloneParis: Difusión, Editions Maison des langues: 79-100.

Janowska, I. 2011. Podejście zadaniowe do nauczania i uczenia się języków obcych. Na przykładzie języka polskiego jako obcego. Kraków: Universitas.

Kruszewski, K. (red.) 2005. Sztuka nauczania. Czynności nauczyciela. Warszawa: Wydawnictwo Naukowe PWN.

Nunan, D. 2004. Task-Based Language Teaching. Cambridge: Cambridge University Press.

Rada Europy. 2003. Europejski system opisu ksztatcenia językowego: uczenie się, nauczanie, ocenianie. Warszawa: Wydawnictwa CODN.

Schmidt, R. 1990. „The role of consciousness in second language learning”. Applied Linguistics 11: 129-158.

Skehan, P. 1998. A cognitive approach to language learning. Oxford: Oxford University Press.

Springer, C. 2009. „La dimension sociale dans le CECR: pistes pour scénariser, évaluer et valoriser l'apprentissage collaboratif". Le français dans le mondeRecherches et applications 45: 25-34.

Wilczyńska, W. 1999. Uczyć się czy być nauczanym? O autonomii w przyswajaniu języka obcego. Warszawa: Wydawnictwo Naukowe PWN.

Willis, J. 1996. A Framework for task-based language teaching. New York: Longman. 